\section{A COMPANION TO WITTGENSTEIN}

A Companion to Wittgenstein's 'Tractatus'

By Prof. Max Black. Pp. xv+451. (Cambridge: At the University Press, 1964.) 55s. net.

$\mathrm{T}$

HE name of Ludwig Wittgenstein (1889-1951) stands alone among philosophers of this century. In stature, he rises above his contemporaries, not so much for his achievements (great as they were) as for his supreme intellectual courage. The youngest of a cultured Viennese family - and a close friend of Johannes Brahms-he was always fascinated by machines. Through them he was led to a deep study of abstractions, and so to the composition of his Tractatus Logico-Philosophicus, the manuscript of which was found in his rucksack when he was taken a prisoner of war by the Italians in 1918 .

Wittgenstein's extreme desire for compression (the whole book is only some twenty-thousand words in length) makes a text of great difficulty in any event, almost incomprehensible to the most ardent of readers. That is why students will give a ready welcome to this Companion by Prof. Max Black. He tells us how he has worked from the original German (and what lucid German it is), but he has not omitted to provide a concordance which reveals the magnitude of the task involved in obtaining the best exegesis.

The scheme of the present commentary is briefly as follows. After some essential introductory matter, the main thesis is divided into a number of 'instalments', prefaced by appropriate preliminary statements. In detail, these are reinforced by comments on some of the more intractable expressions, then by quotations from earlier sketches and unpublished manuscripts. Next come some clarifications of Wittgenstein's views (mostly concerning Russell and Frege), followed by cross-references. In addition, the reader will find two helpful features: first, some free paraphrases of exceptionally obscure passages and, secondly, a number of short explanatory articles on matters arising. At the end is a bibliography, a number of tables and a list of signs.

A good test of the value given by a cicerone is the guidance offered to his followers in orientating them in the right direction to grasp the essentials of the original plane of discourse, and here Prof. Black can claim considerable success. If we take up the argument on page 378 ("Is the Tractatus self-defeating?") we shall see what this means.

Wittgenstein opined that his work would be incomprehensible to anyone who had not already thought the thoughts expressed in it, which is almost to say that metaphysics-on which he set great store-was as nonsensical a discipline as ever it was and, moreover, impotent in helping us to understand the world. The Vienna Circle once desired to regard the Tractatus as a positivistic tract. Much of this travail, however, is seen to be the result of stretching ordinary language to (nearly) unbelievable lengths, making bare recognition, let alone verification, very precarious. To me this suggests a species of linguistic topology wherein continuous deformations may bring about properties neither senseless nor useless. Wittgenstein delighted in such metaphors as scaffolding and ladders. He may be obliged, we are told, to discard the latter after use, but it does not seem imperative to deny their existence. In any event, a system of scaffolding can be a beautiful thing in its own way, and only adds to the mystery of the building while in position: indeed it is an act of faith to erect it. Wittgenstein disdained neither mysteries nor myths and, as Prof. Black remarks, mathematicians have often laboured with symbols the justification for which was at first by no means obvious. Sometimes in the end they have merited nothing better than rejection. But there is no knowing without trying, and that was Wittgenstein's life.

One disposition is needful, namely, a firm resolve not to liken the Tractatus, or anything in it, to common sense, science, logic or mathematics, in an effort to grip it. The late C. K. Ogden's rendering of Wittgenstein's final remark (No. 7) has become too famous to omit: "Whereof one cannot speak, thereof one must be silent". F. I. G. RAWLINS

\section{AMERICAN PHYSICIAN AND BOTANIST}

David Hosack

Citizen of New York. By Christine Chapman Robbins. Pp. vii + 246. (Philadelphia: The American Philosophical Society, 1964.) 3.50 dollars.

IKE most of the basic sciences, botany owes much to $\mathcal{L}$ the pioneer work of medical men. For example, in the sixteenth century, Dr. William Turner, the medical Dean of Wells, was one of the most original botanists of his age; Linnaeus had a medical qualification, and even in modern times Sir Joseph Hooker, president of the Royal Society, was an M.D. of the University of Glasgow.

One of the pioneer medical botanists in the United States was David Hosack, who was one of the best-known medical practitioners in New York at the end of the eighteenth and beginning of the nineteenth century. To-day, except for an unobtrusive, granite slab in the Channel Gardens of the Rockefeller Center in New York City, Hosack has been largely forgotten. Mrs. Christine Robbins in this biography, which must have entailed considerable research and investigation, has rescued him from time's oblivion and awarded him a garland of posthumous fame.

David Hosack (1769-1835) was the son of Alexander Hosack, a Scot, who after serving in the British Army eventually settled in New York. He married Jane Arden and they had seven children, David being the eldest. Alexander prospered as a merchant, and gave his three sons a good education. David was an arts student at Columbia College, but became an apprentice to Dr. Richard Bayley, a New York surgeon and former pupil of William Hunter in London. David transferred for his final year to the College of New Jersey in Princeton, and graduated B.A. in 1789 . He next worked under Dr. Benjamin Rush at Philadelphia where he graduated M.D. in the University of Pennsylvania in 1791. After practising for a year in Alexandria, Virginia, Hosack, leaving his wife and child to the care of his parents, went to Great Britain for two years of postgraduate study in Edinburgh and London. $\mathrm{He}$ also visited his Scottish kinsfolk at Elgin. In London he attended John Hunter's funeral in 1793, and studied at St. Bartholomew's and St. George's Hospitals. He contributed a paper on "Observations on Vision" to the Royal Society (Phil. Trans. Roy. Soc., Pt. 1,$196 ; 1794)$, and was made Fellow of the Royal Society in 1816. In London he acquired instruction in botany from William Curtis in the botanic garden at Brompton and herborized in Battersea Fields, Hampstead, and Charlton. He became acquainted with leading English botanists including Sir Joseph Banks, and was elected a Fellow of the Linnean Society. He took back with him to New York an extensive library, chemical apparatus, an herbarium and other collections paid for by his indulgent father.

On Hosack's return he became professor of botany at Columbia College (1795-1811) and was physician to the New York Hospital. He soon had an extensive and lucrative practice. He was the first in the United States to ligature the femoral artery for aneurism. Hosack never made any great botanical discovery, but he taught the science and founded the Elgin Botanic Garden in 1801, the first of the kind in the United States, on the site of the present Rockefeller Center. The subsequent fate of this garden, Hosack's other appointments at medical schools, 